\title{
Factor Influencing Marketable and Marketed Surplus of Major Crops in Morena District
}

\author{
Kiran Sharma*, A. M. Jaulkar and Rahul Kumar \\ Department of Agricultural Economics, RVSKVV - College of Agriculture, \\ Gwalior (M.P.), India \\ *Corresponding author
}

\begin{abstract}
A B S T R A C T
Keywords

Marketable surplus crops,

Morena District

Article Info

Accepted:

12 October 2020

Available Online:

10 November 2020

The present study entitled Factor Influencing Marketable and Marketed Surplus of Major Crops in Morena District was undertaken to calculate the predictable regression parameters in factor of mustard, wheat, pigeonpea and bajra was found to be less than marketable surplus in different crops. Marketed surplus of pigeonpea was found to be more than marketable surplus. Marketable surplus of mustard, wheat, pigeonpea and bajra was initiated to be highest in wheat followed by mustard, pigeonpea and bajra. Marketed surplus of mustard, wheat, pigeonpea and bajra was initiated to be highest in pigeonpea followed by wheat, mustard and bajra. The study is based on data collected from 320 farmers (an 80 Mustard growers, 80 Wheat growers, 80 Pigeonpea and 80 Bajra growers) were selected through proportionate random sampling. To calculate the compound growth rates by exponential function was fitted to the indices of area, production and productivity.
\end{abstract}

\section{Introduction}

The agricultural marketing system plays a dual role in economic development of India where resources are primarily agricultural. Increasing demands for money with which to purchase other goods leads to increasing sensitivity to relative prices on the part of the producer and specialization in the cultivation of those crops on which the profits are the maximum, subject to socio - cultural, ecological and economic constraints. The marketing system transmits the crucial price signals. An efficient agricultural marketing system leads to the optimization of resources use and output management. An efficient marketing system can also contributes to an increase in the marketable surplus by scaling down the losses arising out of inefficient processing, storage and transportation. As well, designed system of marketing can effectively distribute the available stock of modern inputs and thereby sustain a faster rate of growth in the agricultural sector. An efficient marketing system also ensures higher level of income for the farmers by reducing the number of middlemen or by restricting the commission on marketing services and the malpractice adopted by them in marketing of farm products. The need for providing 
adequate incentives for increased production is, therefore, very, important and this can be made possible only by stream lining the marketing system.

\section{Materials and Methods}

\section{Selection of the study area}

The present study is confined to Morena district only. This area is purposively selected by the researcher because of his residence and also the ease of collecting appropriate and reliable data within the time and financial constraints. Mustard, Wheat, Pigeonpea and Bajra crops was selected purposively crops are the major crops in Morena district.

\section{Sampling procedure}

For the selection of the sample, multistage sampling technique namely, selection of blocks, villages and farmers was followed

\section{Selection of blocks}

Morena district comprises of 7 blocks i.e. Morena, Porsa, Jaura, Ambah, Kailaras, Sabalgarh and Pahargarh. In the first stage of sampling Morena, Porsa, Jaura and Ambah block was selected because of highest production of Mustard in Morena block, Wheat in Porsa block, Pigeonpea in Jaura block and Bajra in Ambah block.

\section{Selection of villages}

At the second stage, block wise list of villages was prepared. Five villages from each block were selected randomly (total 20 villages).

\section{Selection of farmers}

At the third stage, village wise list of selected crop growers was prepared from each selected village. Among these prepared lists, total 320 farmers (an 80 Mustard growers, 80 Wheat growers, 80 Peogenpea and 80 Bajra growers) were selected through proportionate random sampling.

\section{Collection of data}

Depending upon the objectives of the study, primary data was used the primary data were collected from selected major crops growers (respondents) using pre-tested questionnaire, through survey method. Each selected respondents were approached personally for recording relevant data.

\section{Factors influencing marketable surplus and marketed surplus}

The Marketable Surplus differs from region to region, within the same region, and even from crop to crop. Some of the factors affecting marketable surplus on a particular farm are:

Size of Holding: There is a positive relationship between the size of the holding and marketable surplus.

Production: The higher the production, the larger will be the marketable surplus.

Price of the Commodity: There exists both positive and negative relation between both, depending upon whether one considers short run or long run.

Size of Family: There is a negative relationship between family size and marketable surplus.

Requirement of Seed and Feed: The higher the requirement for seed and feed, the smaller the marketable surplus.

Nature of the Commodity: The marketable surplus of non-food crops is generally higher than that of for food crops, as in case of former family consumption is either very small part of the total output or is negligible. Among various food crops, consumption of sugarcane, spices and oilseeds etc., require some kind of processing before final 
consumption; so marketable surplus as a proportion of total output is larger for such crops than for other food crops.

Consumption Habits: Marketable surplus is inversely related to the consumption habits of people.

\section{Results and Discussion}

\section{Factors influencing marketed surplus}

The predictable regression parameters of the marketed surplus model are shown in Table 1. As estimated, variables like size of family (no.), size of land holding, size of area under crops, price of the commodity (Rs/qtl), consumption habit (qtl), total production, Nature of commodity and Requirements for seed/feed/wages as independent variable by using multiple regression model (Fig. 1).

It is analysis from the data that the fitted function for mustard was found to be good fit as the coefficient of multiple $R$ value was 7 per cent discovered that the fitted function able to explain more identified independent variable. Amongst all the independent variables i.e. total production were found to be positive and significant. The independent variables like price of the commodity (Rs/qtl) were found to be negative and significant. The independent variables like size of land holding, size of area under crops, consumption habit (qtl) and Requirements for seed/feed/wages were also found nonsignificant and size of family (no.) were found to be negative and non-significant.

It is analysis from the data that the fitted function for wheat was found to be good fit as the coefficient of multiple $\mathrm{R}$ value was 64 per cent discovered that the fitted function able to explain more identified independent variable. Amongst all the independent variables i.e. size of family (no.), size of land holding, size of area under crops, consumption habit (qtl), total production and Requirements for seed/feed/wages were also found positive and significant. The price of the commodity (Rs/qtl) were found to be non significant.

It is analysis from the data that the fitted function for pigeonpea was found to be good fit as the coefficient of multiple $R$ value was 46 per cent discovered that the fitted function able to explain more identified independent variable. Amongst all the independent variables like size of family (no.), size of land holding, size of area under crops, consumption habit (qtl), total production and requirements for seed/feed/wages were also found positive and non-significant. The independent variables like price of the commodity (Rs/qtl) were also found nonsignificant.

It is analysis from the data that the fitted function for bajra was found to be good fit as the coefficient of multiple $R$ value was 52 per cent discovered that the fitted function able to explain more identified independent variable. Amongst all the independent variables i.e. size of family (no.), size of land holding, size of area under crops, total production and Requirements for seed/feed/wages were also found positive and significant. The independent variables like consumption habit (qtl) were found to be non significant and price of the commodity (Rs/qtl) were found to be negative and non significant.

\section{Factors influencing marketable surplus}

Factors influencing marketable surplus related to selected crops (mustard, wheat, pigeonpea and bajra) has been analysis and show in table 2. Marketable surplus is total requirement of the farmers. It is analysis from the data that the maximum average total production 317.56 quintal, family consumption 11.90 quintals, seed 12.69 quintals, feed 1.83 quintals, total requirement 26.42 quintals and no wages (Table 2). 
Table.1 Factors influencing marketed surplus

\begin{tabular}{|c|c|c|c|}
\hline Variables & S. D. & Std. error & 'r' value \\
\hline \multicolumn{4}{|c|}{ Mustard } \\
\hline Size of family (no.) & 2.030 & 0.227 & $-0.061^{\mathrm{NS}}$ \\
\hline Size of land holding & 4.621 & 0.517 & $0.054^{\mathrm{NS}}$ \\
\hline Size of area under crops & 4.621 & 0.517 & $0.054^{\mathrm{NS}}$ \\
\hline Price of the commodity (Rs/qtl) & 163.061 & 18.231 & $-0.309^{* *}$ \\
\hline Consumption habit (qtl) & 1.147 & 0.128 & $0.103^{\mathrm{NS}}$ \\
\hline Total production & 102.649 & 11.477 & $0.714^{* *}$ \\
\hline Requirements for seed/feed/wages & 1.310 & 0.146 & $0.091^{\mathrm{NS}}$ \\
\hline Multiple R & \multicolumn{3}{|c|}{0.0786} \\
\hline \multicolumn{4}{|c|}{ Wheat } \\
\hline Size of family (no.) & 2.863 & 0.320 & $0.386^{* *}$ \\
\hline Size of land holding & 3.956 & 0.442 & $0.582^{* *}$ \\
\hline Size of area under crops & 3.956 & 0.442 & $0.582^{* *}$ \\
\hline Price of the commodity (Rs/qtl) & 72.717 & 8.130 & $0.052^{\mathrm{NS}}$ \\
\hline Consumption habit (qtl) & 3.058 & 0.342 & $0.411^{* *}$ \\
\hline Total production & 158.978 & 17.774 & $0.600^{* * *}$ \\
\hline Requirements for seed/feed/wages & 5.310 & 0.594 & $0.395^{* *}$ \\
\hline Multiple R & & 0.643 & \\
\hline \multicolumn{4}{|c|}{ Pigeonpea } \\
\hline Size of family (no.) & 3.183 & 0.356 & $0.543^{* *}$ \\
\hline Size of land holding & 2.750 & 0.308 & $0.954^{* * *}$ \\
\hline Size of area under crops & 2.750 & 0.308 & $0.954^{* *}$ \\
\hline Price of the commodity (Rs/qtl) & 68.413 & 7.649 & $0.092^{\mathrm{NS}}$ \\
\hline Consumption habit (qtl) & 0.383 & 0.043 & $0.514^{* *}$ \\
\hline Total production & 55.146 & 6.166 & $1.000^{* *}$ \\
\hline Requirements for seed/feed/wages & 0.378 & 0.042 & $0.488^{* *}$ \\
\hline Multiple R & \multicolumn{3}{|c|}{0.4683} \\
\hline \multicolumn{4}{|c|}{ Bajra } \\
\hline Size of family (no.) & 2.506 & 0.280 & $0.414^{* *}$ \\
\hline Size of land holding & 3.147 & 0.352 & $0.523^{* *}$ \\
\hline Size of area under crops & 3.147 & 0.352 & $0.523^{* *}$ \\
\hline Price of the commodity (Rs/qtl) & 70.117 & 7.839 & $-0.005^{\mathrm{NS}}$ \\
\hline Consumption habit (qtl) & 0.525 & 0.059 & $0.198^{\mathrm{NS}}$ \\
\hline Total production & 31.331 & 3.503 & $0.551^{* *}$ \\
\hline Requirements for seed/feed/wages & 3.588 & 0.401 & $0.345^{* *}$ \\
\hline Multiple R & \multicolumn{3}{|c|}{0.5235} \\
\hline
\end{tabular}


Table.2 Factors influencing marketable surplus

\begin{tabular}{|c|c|c|c|c|c|c|c|}
\hline \multirow{2}{*}{$\begin{array}{c}\text { Total } \\
\text { Production }\end{array}$} & \multicolumn{4}{|c|}{ Requirement } & \multirow{2}{*}{$\begin{array}{c}\text { Total } \\
\text { Require } \\
\text { ment }\end{array}$} & \multirow{2}{*}{$\begin{array}{c}\text { Marketable } \\
\text { Surplus }\end{array}$} & \multirow{2}{*}{$\begin{array}{c}\text { Marketed } \\
\text { Surplus }\end{array}$} \\
\hline & $\begin{array}{c}\text { Family } \\
\text { consumption }\end{array}$ & Seed & Feed & wages & & & \\
\hline 78.66 & 0.35 & 1.69 & 0.33 & 00 & 2.37 & 76.29 & 36.38 \\
\hline 145.03 & 7.95 & 9.7 & 1.12 & 00 & 18.77 & 126.26 & 44.19 \\
\hline 62.31 & 0.94 & 0.21 & 00 & 00 & 1.15 & 61.16 & 61.17 \\
\hline 31.56 & 2.66 & 1.09 & 0.38 & 00 & 4.13 & 27.43 & 18.43 \\
\hline 317.56 & 11.90 & 12.69 & 1.83 & 00 & 26.42 & 291.14 & 160.17 \\
\hline
\end{tabular}

Fig.1 Marketable and marketed surplus in different crops (Average)

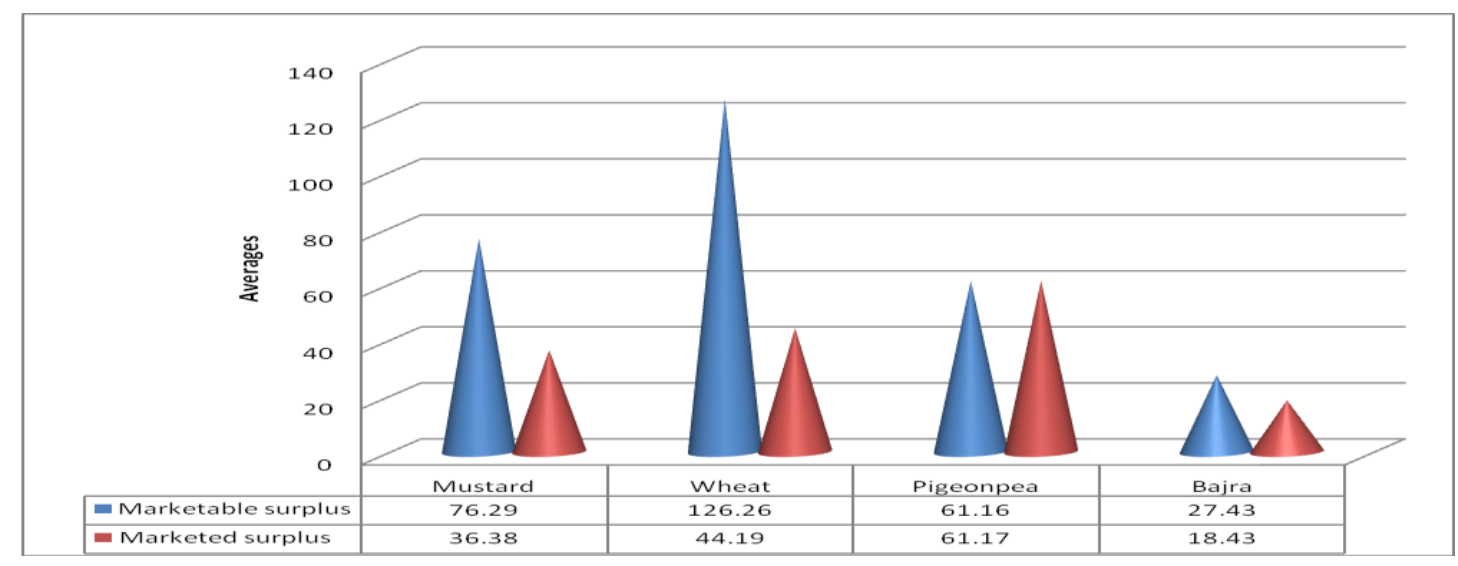

It is evaluated from the data that marketed surplus of mustard, wheat and bajra was found to be less than marketable surplus in different crops. Marketed surplus of pigeonpea was found to be more than marketable surplus. Marketable surplus of mustard, wheat, pigeonpea and bajra was initiate to be maximum in wheat 126.26 quintals followed by mustard 76.29 quintals, pigeonpea 61.16 quintals and bajra 27.43 quintals. Marketed surplus of mustard, wheat, pigeonpea and bajra was initiate to be maximum in pigeonpea 61.17 quintals followed by wheat 44.19 quintals, mustard 36.38 quintals and bajra 18.43 quintals.

In conclusion factors influencing marketable surplus related to selected crops (mustard, wheat, pigeonpea and bajra) has been analysis. Marketable surplus is total requirement of the farmers. It is evaluated from the data that marketed surplus of mustard, wheat and bajra was found to be less than marketable surplus in different crops. Marketed surplus of pigeonpea was found to be more than marketable surplus. Marketable surplus of mustard, wheat, pigeonpea and bajra was initiated to be highest in wheat followed by mustard, pigeonpea and bajra. Marketed surplus of mustard, wheat, pigeonpea and bajra was initiated to be highest in pigeonpea followed by wheat, mustard and bajra.

\section{References}

Agarwal, N.L. (1970). "Agricultural Marketing in India: Some Facts and emerging Issues", Agricultural Situation in India, 25(1).

Birachi, E. A. Ochieng, J. Wozemba, D. Ruraduma, C. Niyuhire, M. C. 
Ochieng, D. (2011). "Factors influencing small-holder farmers' bean production and supply to market in Burundi." African Crop Science Journal; 19(4): 335-342.

Malik, D.P., Singh, S.N. and Rai, K.N. (1992). "Factors affecting the marketed and marketable surplus of Wheat and Paddy in Kurukshetra district of Haryana", Agricultural Marketing, 35(2): 21-26.

Reddy, M.J.M. (1987). "Marketable Surplus in Paddy - A Regression Analysis", Agricultural situation in India, Vol. 41, PP. 823-825.

Sharma, K.L. and M.P. Gupta (1970). "Study of farm factors determining Marketed Surplus of Bajra in Jaipur District." Indian Journal of Agricultural Economics. 25 (October - December): 64-68.

Singh, A. J. and Singh, I. (1992). "An analysis study of pattern and factor affecting marketed surplus in Punjab: A size-wise analysis" Indian Journal of Agricultural Marketing, 6(1): 12-20.

Upender, P. (1992). "Marketable Surplus Functions -A Regression Analysis" Journal of Rural Development, 11(1): 34-48.

Verma, Ajit, Vinay Kumar and Pradip Kumar (2009). "Studies on dimension and magnitude of factor affecting the marketed surplus of wheat" Plant Archives; 9(1): 411-412.

Virendra Kumar Chauhan and Ramesh Singh (2002). "Marketed Surplus of Paddy A Regression Analysis", Indian Journal of Agricultural Marketing, 45(2): 25-28.

Vyas, V.S. and M.H. Maharaja (1966). "Factors Affecting Marketable Surplus and Marketed Surplus in Arthas Vikas, 2(1): 59 .

\section{How to cite this article:}

Kiran Sharma, A. M. Jaulkar and Rahul Kumar. 2020. Factor Influencing Marketable and Marketed Surplus of Major Crops in Morena District. Int.J.Curr.Microbiol.App.Sci. 9(11): 1582-1587. doi: https://doi.org/10.20546/ijcmas.2020.911.187 